\title{
The Role of Motivation and Professional Competence in Improving Teacher Performance
}

\author{
Muhammad Fachmi ${ }^{1 *}$, Mustafa ${ }^{2}$, Ali Murdhani Ngandoh ${ }^{3}$ \\ 'Management, STIE Amkop Makassar, Indonesia \\ ${ }^{2}$ Management, Universitas Muslim Maros, Indonesia \\ ${ }^{3}$ Management, STIE Nobel Indonesia Makassar, Indonesia \\ "Corresponding author: muhammadfachmi22@gmail.com
}

\begin{abstract}
This study aims to analyze the role of work motivation and professional competence in improving the performance of Vocational High School teachers in Soppeng Regency, as well as which variables are most dominant in influencing the improvement of teacher performance. Researchers took a sample of 72 teachers from five vocational schools in Soppeng Regency with the sampling technique, namely random sampling. The data analysis technique used is multiple linear regression analysis with SPSS software. The results showed that work motivation has a positive and significant effect on teacher performance, meaning that if the work motivation is higher, the teacher's performance will also increase. In addition, professional competence also has a positive and significant effect on teacher performance, so that if professional competence is getting better, teacher performance will also increase. Researchers also found that work motivation is the most dominant variable affecting the improvement of teacher performance in schools.
\end{abstract}

Keywords: Work Motivation, Professional Competence, Teacher Performance

Abstrak: Penelitian ini bertujuan untuk menganalisis peranan motivasi kerja dan kompetensi profesional dalam meningkatkan kinerja guru Sekolah Menengah Kejuruan di Kabupaten Soppeng, serta variabel manakah yang paling dominan dalam mempengaruhi peningkatan kinerja guru. Peneliti mengambil sampel sebanyak 72 orang guru yang berasal dari lima SMK di Kabupaten Soppeng dengan teknik penentuan sampel yaitu dengan random sampling. Teknik analisis data yang digunakan yaitu analisis regresi linier berganda dengan software SPSS. Hasil penelitian menunjukkan bahwa motivasi kerja berpengaruh positif dan signifikan terhadap kinerja guru, artinya jika motivasi kerja semakin tinggi maka kinerja guru juga akan semakin meningkat. Disamping itu, kompetensi profesional juga berpengaruh positif dan signifikan terhadap kinerja guru, sehingga apabila kompetensi profesional semakin baik maka kinerja guru juga akan mengalami peningkatan. Peneliti juga menemukan bahwa motivasi kerja merupakan variabel yang paling dominan mempengaruhi peningkatan kinerja guru di sekolah.

Kata Kunci: Motivasi Kerja, Kompetensi Profesional, Kinerja Guru

\section{INTRODUCTION}

Education is something that is very urgent in human life, in fact, education has been able to lead humans to a more adaptive life, education has been in line with the birth of humans, when humans appear in that realm education also emerges, education is also the most important investment for the nation, especially for a developing nation, development is only prepared through education (Minarti, 2011). In line with this, that education is one means of improving the quality of human resources.

Law Number 14 of 2005 concerning teachers and lecturers explains that teachers are professional educators with the main task of educating, teaching, guiding, directing, training, 
assessing, and evaluating students in early childhood education through formal education, basic education, and education medium. Therefore, the role of teachers in the delivery of formal education is very dominant to achieve quality education. To achieve quality education, professional, qualified teachers who meet the required competencies are needed.

Teacher performance is interesting to study where researchers observed that many teachers have not shown their performance optimally in school, including some teachers who lack the ability to manage learning when in class because they did not make preparations, some teachers also have not mastered the learning material taught to students. In class, some teachers are less motivated to show work performance at school which according to some teachers that despite showing good performance, the school has not been maximal in accommodating teachers who show good achievement in the form of awards, and some teachers have also not been able to develop a curriculum or syllabus well at school. This situation illustrates that teacher performance is still not optimal.

In this case, according to Yudistiro (2015), teacher performance will be good if the teacher has implemented elements consisting of loyalty and high commitment to teaching tasks, mastering and developing learning materials, discipline in teaching and other tasks, creativity in implementing teaching, cooperation with all school members, leadership that is a role model for students, a good personality, honest and objective in guiding students, and responsibility for their duties.

Efforts to maximize teacher performance can be done by increasing teacher motivation in schools. Motivation is very important for teachers because through motivation there will be encouragement, strength, and high enthusiasm to achieve the best work standards for teachers in schools. Danim (2004) states that motivation is defined as encouragement, strength, need, enthusiasm, role model, or psychological mechanism that encourages individuals or groups of people to achieve certain results according to what they want. That is, a teacher who is motivated when there are encouragement and strength to show the best work results in school. As in Mafudah and Asrori's (2016) research, work motivation has a positive and significant effect on the performance of vocational teachers. Likewise with Eros (2014), Hardono, et al., (2017), \& Aprida, et al., (2020) that there is a positive and significant influence on teacher work motivation on teacher performance. However, this is different from the research conducted by Sampurno \& Wibowo (2015) that motivation does not significantly affect teacher performance.

A teacher in carrying out his/her duties and responsibilities and is considered to be performing well, as well as required to have competence, one of which is professional competence. In Article 1 of Law No. 14 of 2005 on Teachers and Lecturers (hereinafter abbreviated as UUCD) it is stated that teachers are professional educators with the main task of educating, teaching, guiding, directing, training, assessing, and evaluating students in early childhood education through formal education, basic education, and secondary education. A professional teacher as referred to in this article is a job or activity that is carried out by a person and becomes a source of living income that requires expertise, proficiency or skills that meet certain quality standards or norms and require professional education Therefore, mastery of material that is broad and deep in this case includes the mastery of other academic abilities that act as a added value of teacher professionalism. As in research by Sutomo (2016) and Nasri, et al., (2018) who found that professional competence has a positive and significant effect on teacher performance.

Maximizing teacher performance is needed, because of the phenomenon that teacher performance is still not optimal. As seen in several Vocational High Schools in Soppeng Regency, where researchers see that some teachers have not maximally shown their performance, for example in making the design of learning activities still not according to the expectations of the principal, less varied in creating classroom learning, resulting in a lot of students who pay less attention to the teacher's explanation, as well as various other phenomena. Through this description, that there are still differences in the results of previous 
studies, so that to fill this gap, researchers need to conduct further research at Vocational High Schools in Soppeng Regency. Therefore, the aim of this study was to analyze the influence of motivation and professional competence on teacher performance.

In line with the objectives of this study, the empirical research model can be described as a reference in determining the research hypothesis as follows:

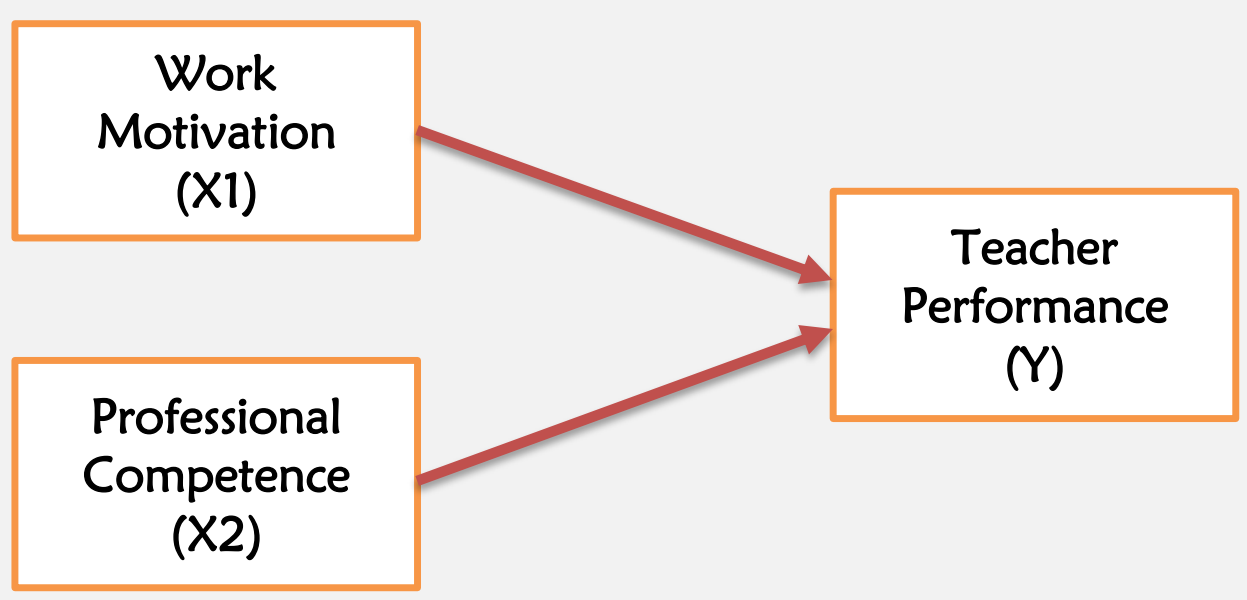

Figure 1. Empiric Model

Based on the empiric model in Figure 1 which refers to the theory and results of previous research, the hypothesis in this study is as follows:

1. Work Motivation has a positive and significant effect on teacher performance

2. Professional competence has a positive and significant effect on teacher performance

3. Work Motivation has the most dominant influence on teacher performance

\section{METHOD}

This research is classified as a causal comparative study, where the characteristic is looking for a cause-and-effect relationship between two or more variables. Comparative causal research is a type of ex post facto research, that is, a type of research on data collected after a fact or event occurs. The research location is at the State Vocational High School (SMK) in Soppeng Regency, namely SMK Negeri 1 Soppeng, SMK Negeri 2 Soppeng, SMK Negeri 3 Soppeng, SMK Negeri 4 Soppeng, and SMK Negeri 5 Soppeng. As for the sample in this study were 72 teachers at State Vocational High School. The sampling technique is random sampling where this method is used to select samples from the population in a random way, so that each member of the population has an equal chance of being taken as a sample.

The data analysis tool used in this study was a study with the Multiple Linear Regression Model with the help of SPSS software. Multiple linear regression analysis is a statistical technique used to predict how the condition or influence of the independent variables, namely work motivation and professional competence, on the dependent variable, namely teacher performance. To test the hypothesis, the $t$ test is carried out at a significant level of 0.05 (95\% confidence level).

\section{RESULT AND DISCUSSION \\ Validity and Reliability Test}

The validity of the instrument was tested by means of the Pearson Correlation analysis tool between items and the total item, and was declared valid if it met the minimum 
requirements of $r=0.3$. So if the correlation between the item score and the total score is less than 0.3 , the item score in the instrument is declared invalid. While the reliability of the instrument was tested using Alpha Cronbach analysis tool. The criteria used to determine a reliable instrument is if the reliability coefficient gives a value of $\alpha>0.60$.

The work motivation variable $(X 1)$ is measured based on seven indicators, with a total of 7 items according to the established instrument, the professional competency variable (X2) is measured by six indicators, and the employee performance variable (Y1) is measured by seven indicators. The results of testing the validity and reliability of the variable instrument work motivation, professional competency, and teacher performance can be seen in Table 1.

Table 1. Test Results of the Validity and Reliability

\begin{tabular}{|c|c|c|c|}
\hline Variable & Items & r-value & Cronbach's Alpha \\
\hline \multirow{7}{*}{ Work Motivation (X1) } & X1.1 & 0,845 & \multirow{7}{*}{0,932} \\
\hline & $\mathrm{X} 1.2$ & 0,873 & \\
\hline & $\mathrm{X} 1.3$ & 0,875 & \\
\hline & X1.4 & 0,865 & \\
\hline & $\mathrm{X} 1.5$ & 0,717 & \\
\hline & $\mathrm{X} 1.6$ & 0,871 & \\
\hline & $\mathrm{X} 1.7$ & 0,881 & \\
\hline \multirow{6}{*}{ Professional Competency (X2) } & $\times 2.1$ & 0,898 & \multirow{6}{*}{0,926} \\
\hline & $\times 2.2$ & 0,814 & \\
\hline & $\mathrm{X} 2.3$ & 0,880 & \\
\hline & $\times 2.4$ & 0,760 & \\
\hline & $\times 2.5$ & 0,913 & \\
\hline & $\times 2.6$ & 0,912 & \\
\hline \multirow{7}{*}{ Teacher Performance (Y) } & Y.1 & 0,825 & \multirow{7}{*}{0,930} \\
\hline & Y.2 & 0,921 & \\
\hline & Y.3 & 0,919 & \\
\hline & Y.4 & 0,841 & \\
\hline & Y.5 & 0,701 & \\
\hline & Y.6 & 0,863 & \\
\hline & Y.7 & 0,871 & \\
\hline
\end{tabular}

Based on Table 1, it can be seen that all items in each variable have a correlation value above 0.30 , so that all statement items used in the questionnaire are declared valid. Likewise, the coefficient value of Cronbach's alpha is above 0.60 so that the variable instruments of work motivation (X1), professional competence $(\mathrm{X} 2)$, and teacher performance $(\mathrm{Y})$ are declared reliable.

\section{Hypothesis Testing Results}

The results of the calculation of the multiple linear regression test on the influence model of work motivation (X1) and professional competence (X2) on teacher performance $(\mathrm{Y})$ are shown in Table 2. The multiple linear regression equation model obtained based on the results of the regression analysis is as follows:

$$
Y=4,589+0,498 \times 1+0,425 \times 2+e
$$

Where:

$\mathrm{Y}=$ teacher performance

$\mathrm{X} 1=$ work motivation

$\mathrm{X} 2$ = professional competence 
$\mathrm{e}=$ residual

Table 2. Hypothesis Testing Results

\begin{tabular}{c|c|c|c|c|c|}
\hline Models & Coefficients & Beta & Calc t-value & Sig & remark \\
\hline (Constant) & 4,589 & - & 2,571 & 0,012 & - \\
\hline Work Motivation & 0,498 & 0,518 & 3,689 & 0,000 & Significant \\
\hline Professional Competence & 0,425 & 0,379 & 2,700 & 0,009 & Significant \\
\hline
\end{tabular}

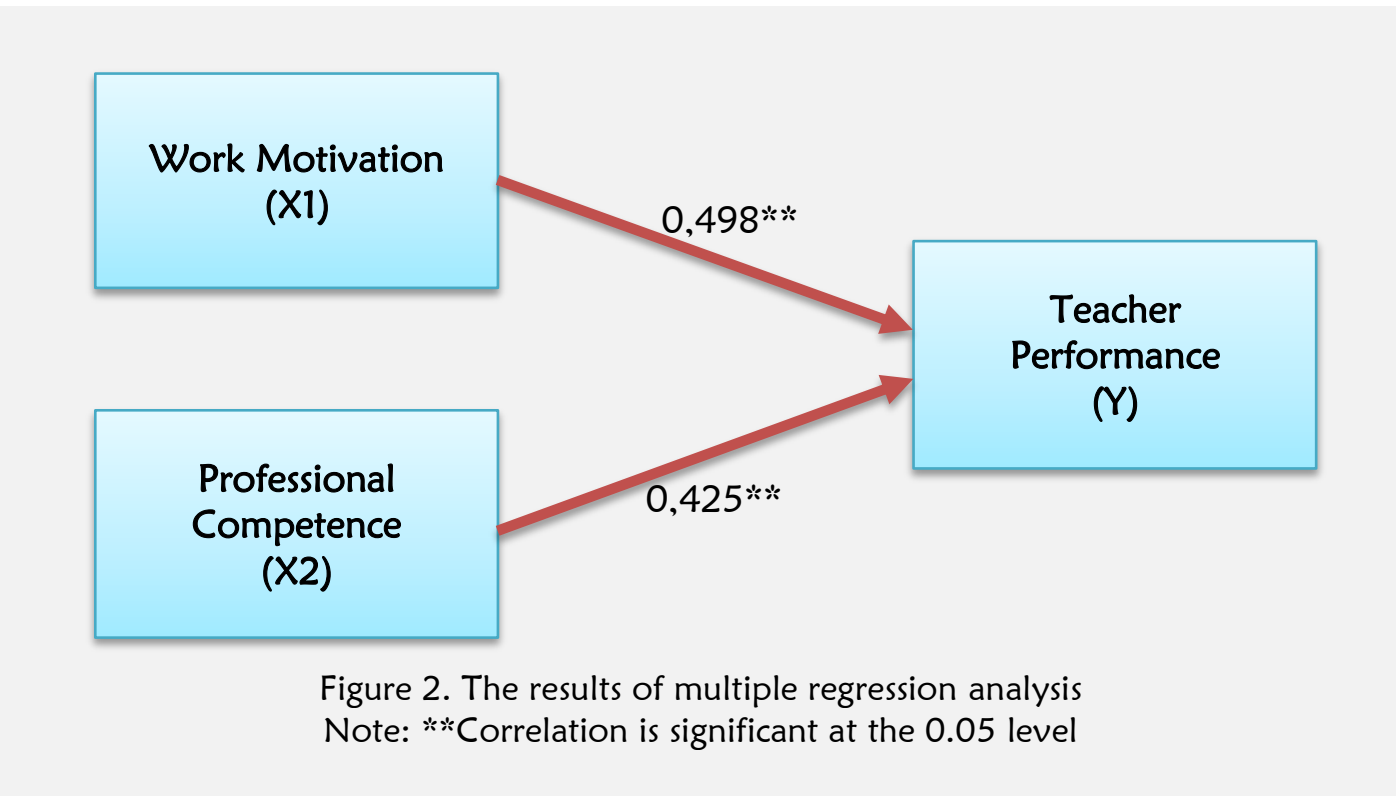

Based on the results of regression analysis, it was found that work motivation has a positive and significant effect on teacher performance, the calculated $t$-value was 3,689 with the Sig. $t$ of 0,000 . From the statistical table with an alpha of $5 \%$, the $t$-table is 1,667 . Because the value of $t$-count $>$ t-table $(3,689>1,667)$, and the probability value $<0,05(0,000<$ $0,05)$, the hypothesis is accepted. This indicates that there is a significant influence between work motivation on teacher performance. Given that the coefficient is positive $(0,498)$ indicates a positive or unidirectional relationship. This means that the better work motivation, the better the teacher's performance level.

Furthermore, in the second hypothesis, namely professional competence has a positive and significant effect on teacher performance, the $t$-value is 2,700 with a Sig. $t$ of 0,009 . From the statistical table with an alpha of $5 \%$, the $t$-table is 1,667 . Because the value of $t$-count $>t$ table $(2,700>1,667)$, and the probability value $<0,05(0,009<0,05)$, the hypothesis is accepted. This indicates that there is a significant influence between professional competence on teacher performance. Given that the coefficient is positive $(0,425)$ indicates a positive or unidirectional relationship. This means that the better a person's professional competency level, the better the teacher's performance level.

To determine the independent variable that most dominantly affects the dependent variable, it can be seen from the standardized regression coefficient (or beta). The highest value indicates the most dominant variable. Based on Table 2, it can be concluded that the work motivation variable (Y1) is the most dominant variable affecting teacher performance, with a beta coefficient of 0.518 , compared to other variables, namely professional 
competence (0.379). Therefore, the third hypothesis is accepted, meaning that work motivation has the most dominant influence on teacher performance.

\section{Discussion}

Based on the research that has been done, it is found that the work motivation variable has a positive and significant effect on teacher performance. That is, the better the level of teacher work motivation, the better the level of teacher performance, conversely the less good the level of teacher work motivation, the less good the teacher's performance level. In this case, a teacher will teach well because there is something that encourages or motivates him to work. This means that a teacher is enthusiastic in carrying out his duties as an educator because of the high work motivation to fulfill the desired needs. The hopes and desires of a teacher will influence his personality to determine various views on behavior, especially in the learning process at school.

Teacher work motivation (X2) is measured in seven indicators, namely completing tasks with full responsibility (X2.1), carrying out tasks with awareness without supervision (X2.2), having exemplary attitude and behavior (X2.3) ), Dare to take and assume risks (X2.4), Active in giving advice (X2.5), Need for achievement (X2.6), and Need for affiliation (X2.7). Of the seven indicators, respondents rated the lowest on the indicator Dare to take and assume risks (X2.4). This means that teachers have not been motivated to dare to take and take risks in making learning innovations in schools, and this shows that teachers' work motivation is still low. Therefore, it needs encouragement from the principal so that teachers dare to innovate in class learning in accordance with current conditions to make the learning atmosphere more attractive to students and its impact on the quality of education that is getting better. The results of this study are in line with previous studies, namely Mafudah and Asrori's (2016) research, work motivation has a positive and significant effect on the performance of vocational teachers. Likewise with Eros (2014), Hardono, et al., (2017), \& Aprida, et al., (2020) that there is a positive and significant influence on teacher work motivation on teacher performance.

This study also proves that professional competence has a positive and significant effect on teacher performance. This means that the better the level of professional competence of the teacher, the better the level of teacher performance, conversely the less good the level of professional competence of the teacher, the less good the level of teacher performance. According to Supriadi (2005) that the characteristics of a professional teacher must have requirements, which include: 1) Having a commitment to the student learning process, 2) Mastering in depth the subject matter and how to teach it, 3) Able to think systematically about what to do and learn from experience, and 4) Is a part of society in their professional environment which allows them to always improve their professionalism.

Teacher professional competence $(X 1)$ is measured in six indicators, namely Planning a teaching and learning program (X1.1), Having an educational foundation (X1.2), Mastering learning material in-depth (X1.3), Carrying out the teaching and learning process (X1.4), Leading / managing the teaching and learning process (X1.5), and assessing the progress of the teaching and learning process $(\mathrm{X} 1.6)$. Of the six indicators, the lowest rated by the respondents is indicator X1.4, namely the professional competence of teachers in implementing the teaching and learning process. This means that teachers need to improve the level of professionalism in the implementation of the teaching and learning process in schools. Therefore, if the teacher has been able to plan the teaching and learning program properly, the teacher will increasingly have a good educational foundation, mastery of learning material in depth, carry out the teaching and learning process optimally, lead / manage the teaching and learning process well, and the teacher is able to make assessments. the progress of the student's teaching and learning process properly, the teacher's performance will increase. This research is in line with Hartana (2013) that Professional Competence has a positive and significant effect on teacher performance, meaning that changes in professional competency 
values have a direct effect on changes in teacher performance, the higher the professional competence of teachers will be followed by an increase in teacher performance or in other words if the professional competence is good. then there will be an increase in teacher performance. Then, Sutomo (2016) and Nasri, et al., (2018) also found that Professional Competence has a positive and significant effect on Teacher Performance.

\section{CONCLUSION}

The conclusion of the research that has been carried out is based on the research results, namely that work motivation has a positive and significant effect on teacher performance. On the other hand, work motivation is also the most dominant variable in improving teacher performance. This means that if you expect the performance of Vocational High School teachers in Soppeng Regency to increase, then the work motivation of teachers in schools needs to be a consideration for the principal to be further improved. A different finding from this study is that not only does work motivation affect teacher performance, but professional competence is also proven to have a positive and significant effect on improving the performance of Vocational High School teachers in Soppeng Regency. This means that the better the professional competence of the teacher, the better the teacher's performance will be.

\section{REFERENCES}

Aprida, Y., Fitria, H., \& Nurkhalis, N. (2020). Pengaruh supervisi kepala sekolah dan motivasi kerja guru terhadap kinerja guru. Journal of Education Research, 1(2), 160-164.

Danim, S. (2004). Pengantar Studi Penelitian Kebijakan. Bandung: Bumi Aksara

Eros, E. (2014). Pengaruh motivasi dan kedisiplinan kerja guru terhadap kinerja guru di smp negeri kecamatan brebes kabupaten brebes jawa tengah. Jurnal Administrasi Publik dan Birokrasi, 1(1), 72280.

Hardono, H., Haryono, H., \& Yusuf, A. (2017). Kepemimpinan Kepala Sekolah, Supervisi Akademik, dan Motivasi Kerja dalam Meningkatkan Kinerja Guru. Educational Management, 6(1), 26-33.

Hartana, B. (2013). Pengaruh kompetensi pedagogik, kompetensi profesional, dan motivasi Kerja Terhadap Kinerja Guru. Jurnal Ilmu ekonomi dan Sosial, 2, 147-162.

Mafudah, L., \& Asrori, A. (2016). Pengaruh Pemahaman Kurikulum, Motivasi Kerja, Dan Kepemimpinan Kepala Sekolah Terhadap Kinerja Guru SMK. Economic Education Analysis Journal, 5(2), 389-389.

Minarti, S. (2011). Manajemen Sekolah: Mengolah Lembaga Pendidikan Secara Mandiri. Yogyakarta: Ar-Razz Media.

Nasri, H., Tamsah, H., \& Firman, A. (2018). Pengaruh Kompetensi, Gaya Kepemimpinan, dan Pelatihan, terhadap Kinerja Aparatur Sipil Negara Sekecamatan Binamu Kabupaten Jeneponto. Jurnal Mirai Management, 3(1), 103-120.

Sutomo, Y. (2016). Pengaruh Motivasi dan Kompetensi Profesional terhadap Kinerja Guru Dimoderasi Budaya Organisasional (Studi Kasus pada Guru SMA Negeri Se-kota Tegal) (Doctoral dissertation, Stikubank University). 
Sampurno, D., \& Wibowo, A. (2015). Kepemimpinan Kepala Sekolah, Lingkungan Kerja, Motivasi Kerja, Dan Kinerja Guru di SMK Negeri 4 Pandeglang. Jurnal Pendidikan Ekonomi Dan Bisnis (JPEB), 3(2), 165-180.

Supriadi, Dedi. (2005). Mengankat Citra Dan Martabat Guru. Yogyakarta : Adi Citra Karya

Yudistiro, I. A. (2015). Pengaruh Kecerdasan Emosional, Lingkungan Kerja dan Disiplin Terhadap Kinerja Guru dengan Komitmen Organisasi Sebagai Moderasi. Jurnal Sumber Daya Manusia, 9(1), 38-50. 